\title{
The Power of Prickliness: Iowa's H. R. Gross in the U.S. House of Representatives
}

\section{DAVID W. SCHWIEDER AND DOROTHY SCHWIEDER}

IN 1948 Iowans from the Third Congressional District elected Republican Harold Royce Gross, better known as H. R., to the U.S. House of Representatives. They would reelect him for 12 more terms until his retirement following the elections of 1974. A lifelong maverick, Gross's philosophy centered on an austere fiscal conservatism, and he advanced his views with a determined legislative style. He worked hard in Congress, and he devoted great effort and long hours to his quest to restrain federal spending. Gross was also a bit of a curmudgeon. He had a keen wit and an often sarcastic sense of humor, and he used both to advance his personal legislative agenda. Ultimately, these characteristics and qualities combined to yield a distinctive House career and a national reputation as the "Watchdog of the Treasury."

Gross's style and views dated from his boyhood on a farm in southern Iowa, an experience that left him with a strong sympathy for farmers. His subsequent career choices reflected his perspective: he worked as an editor for the Iowa Union Farmer,

The authors wish to thank the staff of the Hoover Presidential Library for their assistance with this research, especially archivist Matthew Schaefer, who assisted in myriad ways. Dorothy Schwieder also wishes to thank the library for a travel grant that supported her trips to West Branch and Kristy Medanic, a graduate student in the Iowa State University History Department, for helping to locate some library materials.

THE ANNALS OF IOWA 65 (Fall 2006). ( ) The State Historical Society of Iowa, 2006. 
and later as a popular radio broadcaster in the state. A sense that government was failing to serve farmers led him to challenge the sitting Republican governor, George Wilson, in the 1940 Republican primary. Although Gross lost, eight years later he successfully challenged incumbent Third District Republican congressman John W. Gwynne to win election to the U.S. House of Representatives.

Gross's philosophy and style seem to have resonated with a broad swath of the public, and he proved to be a highly effective vote getter. He was far from being a polished politician, but he cultivated his core constituency with a weekly newsletter that delivered his conservative message in a blunt, direct manner, and he provided a variety of services to residents of the Third District. Moreover, he maintained an unswerving advocacy for the district's farm population.

Gross's maverick ways strongly shaped his career in Washington. He was known for his tart tongue and for his willingness to buck House leaders, fellow Republicans, and presidents in his efforts to advance his views. Moreover, his colorful persona made him a popular figure with the press, and he attracted substantial media attention. He was able to leverage his visibility and nonconformity into substantial influence in the House, particularly in the area of spending. Would-be spenders kept Gross in mind, and some spending bills were quietly modified, slashed, or even dropped for fear of attracting the diminutive Iowan's withering scorn (and the press attention that might then follow). There is little evidence that Gross significantly reduced spending in major budget categories, but he often did manage to cut unpopular expenditures such as foreign aid, congressional junkets, and pay raises. More broadly, he made several significant contributions to the chamber. His active legislative style facilitated improved deliberation on many bills, and his untiring scrutiny of fiscal legislation provided a degree of accountability often missing in a body as fragmented as the U.S. House of Representatives.

HAROLD ROYCE GROSS was born on a farm near Arispe in southwest Iowa in June 1899. He attended the local public schools and worked on the family farm. At 16, he dropped out of school and falsified his age in order to join the First Iowa 
Field Artillery. In 1916 he served in the Mexican border campaign. A year later, when the United States entered World War I, he served with the American Expeditionary Forces in France. Following his military discharge, he attended Iowa State College for a brief time, and then found his first true calling when he spent two years studying journalism at the University of Missouri-Columbia. After graduating, he worked for newspapers in Iowa, Texas, Florida, and South Dakota. For a time, he was also employed by the United Press News Service in various parts of the country. In 1929 he married Hazel Webster from the northeastern Iowa town of Cresco. ${ }^{1}$

That same year, Gross's journalism career took a different turn when he went to work for the Iowa Union Farmer. He edited the publication and wrote a column titled "Mustard Seed, Thistles, and Quack Grass," which one scholar later noted "could be informative, humorous and vitriolic all at the same time." Gross soon became a close associate of Milo Reno, the president of the Iowa Farmers Union. Often described as a firebrand, Reno was a well-known figure in Iowa politics. Like Gross, he had been born

1. H. R. and Hazel would have two sons, Philip and Alan. The Harold Royce Gross Papers at the Herbert Hoover President Library, West Branch, Iowa (hereafter cited as Gross Papers), contain a wide variety of archival information on all stages of Gross's life. Published sources on his life are, however, extremely limited. There is no Gross biography. Two theses constitute the bulk of research on his political career. The most informative is James Leon Butler, "A Study of H. R. Gross and How He Gets Elected to Congress" (M.A. thesis, State University of Iowa, 1956). A second thesis covers Gross's speeches on agriculture: Bonita Jean Dostal, "The Speaking of H. R. Gross in the House of Representatives from January 3, 1949 to August 30, 1964 on the Area of Agriculture: Analysis of Arguments, Evidence, and Style" (M.A. thesis, University of Northern Iowa, 1966). In 1968 Donald Feuerhale wrote on Gross's career for his senior thesis at Luther College, "The Impact of One Man in Congress." Most recently, Matthew T. Schaefer contributed a short article, "Harold Royce Gross (1899-1987) and the Curmudgeonly Side of Midwestern Politics," to The American Midwest: An Interpretive Encyclopedia, ed. Richard Sisson, Christian Zacher, and Andrew Cayton (Bloomington and Indianapolis, 2007). In addition, myriad magazine articles have been written on Gross's political career, including articles in Time, Washington Monthly, Nation's Business, Nation's Publisher, Redbook, and National Publisher. Weekly newspapers in Iowa's Third District provided sporadic coverage of Gross's career. The Des Moines Register carried occasional feature stories on Gross but typically only reported on his re-election bids. Gross's hometown paper, the Waterloo Courier, provided more thorough but still limited coverage. The most informative source for Gross's political views is his weekly newsletter to constituents: "On the Capitol Firing Line." 
and raised in southern Iowa, an area known for its thin soil and often hilly terrain, which rendered the region less productive than other parts of the state. Gross would later remember his upbringing: "Our family grubbed it out . . . in the hills and hollows of southern Iowa.... We fought pretty hard in the clay hills of Union County." He added that "one of his first recollections [was] of his father pouring dozens of eggs into a swill barrel for the hogs because eggs weren't worth taking to town to sell." 2

Their shared farm background no doubt helped shape both men's views on agricultural policy. Reno was closely identified with the Iowa Farm Holiday movement, which had responded to the crisis of the Great Depression by agitating for higher farm prices and farm debt relief. Both men believed that the federal government needed to assist the nation's farmers with what they called a "cost of production program." Gross's views about agriculture, evident so early in his career, would persist throughout his life. He believed that farmers were mistreated, often forgotten, and denied adequate compensation for their labors. His solution, discussed frequently in the weekly newsletter that he would later write when serving in Congress, was to provide farmers with the cost of production plus a reasonable profit. Along with shaping his political thinking, Gross's time at the farm paper also helped develop his reputation as a "populist advocate for farmers." 3

In 1935, with Iowa and the rest of the country mired firmly in the Great Depression, Gross switched media and went to work for WHO radio in Des Moines. WHO officials had noticed him when he came to the station to read a message for the Farmers Union. They were so impressed with his voice and delivery that they offered him a job as a newscaster. Gross later observed that WHO hired him despite his employment by "the 'radical' Farmers Union." His chief responsibility was to read

2. Des Moines Register, 11/4/1974; Robert A. McCown, “B. H. Shearer, Country Editor," Books at Iowa, April 1975, 22.

3. "Biographical Sketch, Representative H. R. Gross," Personal, 1930-1979, box 82, Gross Papers; H. R. Gross, interview with Dwight Miller, 1979, transcript, WHO (Des Moines), 1935-1938, box 82, Gross Papers; Butler, "Study of H. R. Gross," 18. The Farmers Union was the first organization to urge adoption of a farm program featuring cost of production plus a reasonable profit for agriculture. 


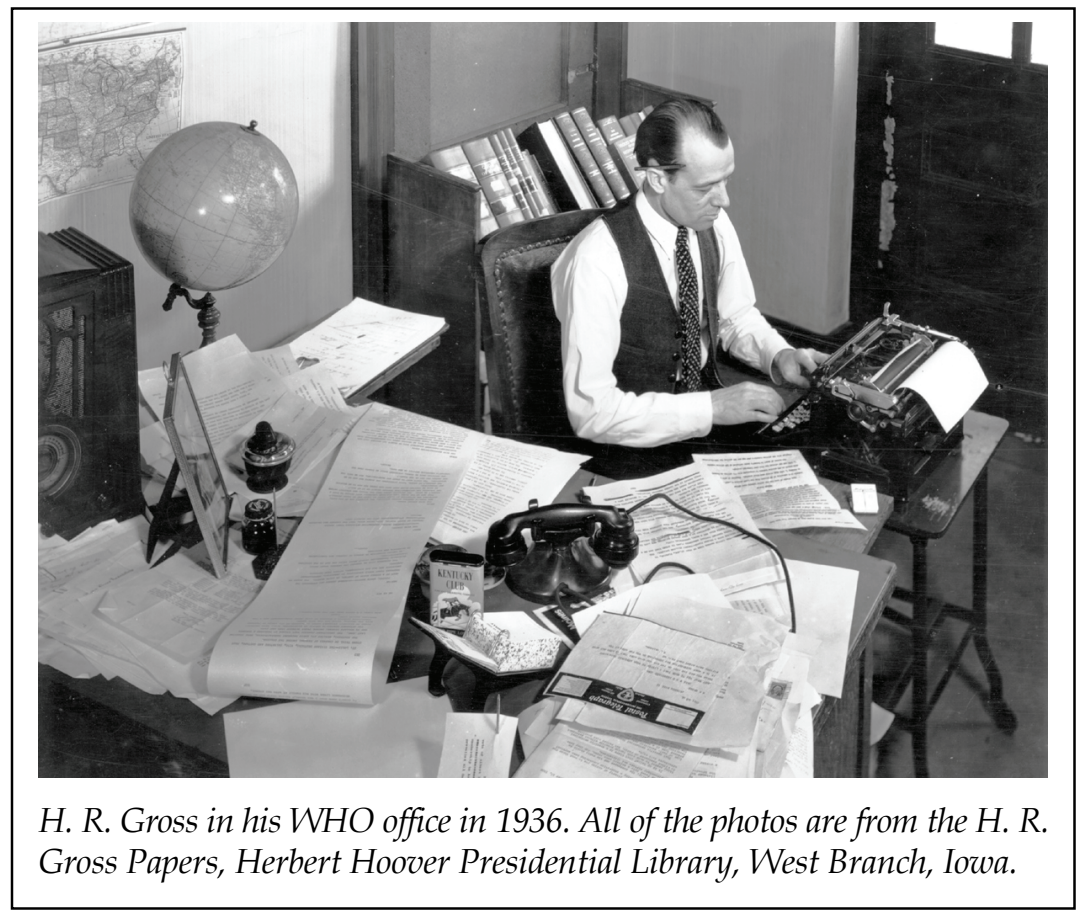

the news several times per day. While at WHO, Gross worked alongside a young sportscaster named Ronald Reagan. Jack Shelley, a longtime WHO newscaster during that period, remembered that Reagan and Gross were "great pals" who spent considerable time together. ${ }^{4}$

Then, as now, WHO was a powerful "clear channel" station, and its signal reached virtually all of Iowa as well as most of the western half of the United States. Judging from the fan mail Gross received from listeners around the country, he was a popular radio personality. In the dozens of letters still in existence-sent from states as diverse as Wyoming, Montana, Arizona, Texas, Oklahoma, Louisiana, and Wisconsin-listeners complimented Gross on his excellent reporting skills and

4. Gross, interview; Jack Shelley, interview with Dorothy Schwieder, Des Moines, 9/29/2006. Jack Shelley remembered that Gross hired him to work at WHO in 1935, and that often they were the only two people in the newsroom. He recalled Gross as a "demanding but fair boss." Jack Shelley, interview with Dorothy Schwieder, Ames, 5/30/2006. 
seemed to regard him as an old friend. A Lafayette, Louisiana, listener wrote: "I think you can rattle off more news in a minute than all other announcers can in fifteen." 5

Gross was particularly well known in Iowa. In his memoirs, William Barlow Quarton III, a pioneer in Iowa's radio industry and a principal in creating WMT radio in Cedar Rapids, wrote that WHO was the most powerful radio station in "this part of the country" in the 1930s. He added that their "two radio personalities - ... Dutch Reagan, who did sports, and H. R. Gross, who did the news at noon ... were the voice of Iowa radio and it was hard to break through that powerful signal." 6

In 1940 Gross took another career turn and decided to try his hand at politics. He resigned his WHO position in order to challenge the incumbent Republican governor, George Wilson, in the Republican gubernatorial primary. Gross's move was motivated, in large part, by his dissatisfaction with Republican agricultural policy. He viewed Wilson as a disappointment because the governor had failed to develop strong aid programs for the state's farmers. Gross had also criticized President Herbert Hoover for similar failings, snidely referring to him as "Dr. Hoover" and "the Great Engineer" and lambasting him for not helping farmers. Leaving few stones unturned, he had also berated the state Republican Party organization. Not surprisingly, party leaders opposed Gross's candidacy. Not only did they believe that Wilson had earned a second term, they also took a dim view of Gross. Beyond his criticisms of the party and its officials, his tenure at the Farmers Union had left the suspicion that he held radical views not representative of Iowa Republicanism. ${ }^{7}$ Whatever the exact basis of the disagreement, Gross's 1940 campaign was an early harbinger of one of the core characteristics

5. A May 1940 survey showed that WHO was heard regularly by 79 percent of Iowa radio listeners; on Iowa farms, the percentage was 85 percent. See Butler, "Study of H. R. Gross," 19.

6. William Barlow Quarton III, Lucky Man: Memories of a Life in Communications (West Branch, Iowa, 2005), 64.

7. Butler, "Study of H. R. Gross," 4, 5, 31, 35, 36; Vernon Louviere, "The House is Losing its 'Conscience,'" Nation's Business, June 1974, 26, in Press Relations, 1949-1974, box 93, Gross Papers; Bert Mills, "The Remarkable Mr. Gross of Iowa," National Publisher, July 1961, 30, in Press Relations, 1949-1974, box 92, Gross Papers. 


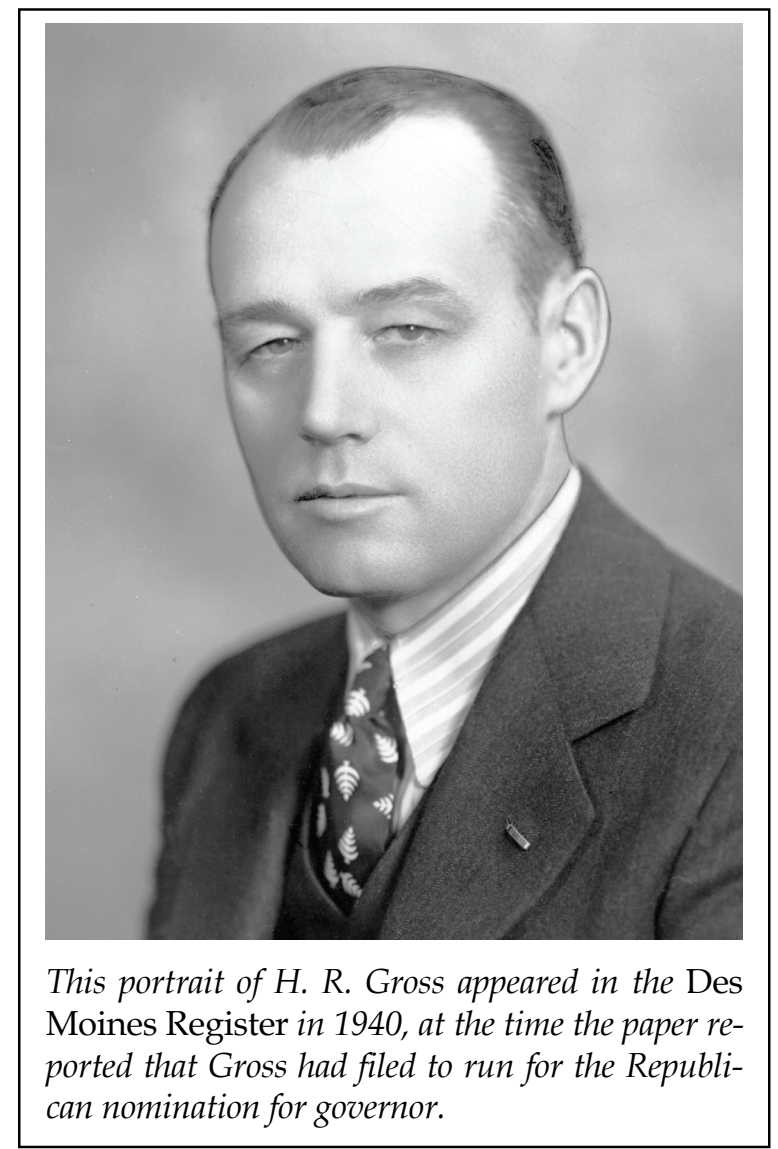

he would later show in Congress: a fierce independence and a contrary - even conflictual - relationship with his own party.

During his time at the Iowa Union Farmer, Gross had also offended other influential constituencies. He had written that "certain editors in the state suffered from 'a chronic case of running off [at] the mouth' and that some newspapers were published by 'ever[-]yapping editors.'" A month before the 1940 primary election, the Cedar Rapids Gazette returned the favor. The paper ran a long editorial lauding the Wilson administration and claiming that Wilson had eliminated "graft, corruption and intolerable waste" in state government spending: "Hold your hat while reading that by the end of this fiscal year . . about $\$ 2,600,000$ will have been slashed from the reckless an- 
nual expenditures of preceding administrations." The editorial also raked Gross, noting that almost a decade earlier, in 1931, he had encouraged the "ill-advised" Cedar County Cow War. (Fearing that their herds would be liquidated if found to be infected with bovine tuberculosis, hard-pressed local farmers had fought disease testing by state veterinarians. That defiant action had focused much negative publicity on Iowa.) The editorial also pointed out that two years later, in 1933, Gross had "publicly endorsed the action of the irresponsibles who dragged Judge C. C. Bradley from his bench" in Le Mars and threatened to lynch him. (The judge had angered local farmers by refusing to halt the process of issuing farm foreclosure notices). The editorial also accused Gross of refusing "to come out into the open," apparently a reference to the fact that Gross campaigned entirely through radio ads, and added that the campaign against Wilson was "of a mysterious and insidiously deceptive nature." The editorial seemingly echoed the views of some Republican officials when it rhetorically cast Gross out of the party, concluding that he was "not a Republican then, is not now. He was and remains an unanchored radical." 8

Wilson prevailed in a "bitterly fought campaign," winning 49.6 percent of the vote to Gross's 43.6 percent. (A third candidate, Irving Knudsen, received 6.6 percent of the vote.) Gross made a respectable showing for an insurgent, especially given his resource constraints. In a later interview, he said that he didn't campaign across the state because he didn't have the money to do so. Jack Shelley thought that Gross's reliance on radio ads had hurt his campaign. While Gross did well in central Iowa, he fared relatively poorly in eastern and western Iowa, where WHO's signal was not as strong. Following his defeat, Gross returned to broadcasting, taking a news commentator job at WLW radio in Cincinnati. Four years later, in 1944, he returned to Iowa to take a similar position at KXEL radio in Waterloo, thus positioning himself for another try at elected office in Iowa. ${ }^{9}$

8. Correspondence, 1930-1940, Farmers Holiday Assoc./Iowa Farmers Union, Personal, 1930-1979, box 82, Gross Papers; Cedar Rapids Gazette, 5/24/1940; Butler, “Study of H. R. Gross," 31.

9. Butler, "Study of H. R. Gross," 38, 42; Gross, interview, 19; Shelley, interview, 5/30/2006. 
In 1948 H.R. Gross returned to the electoral arena. Again, he challenged a Republican incumbent, Third District Congressman John W. Gwynne, and again he bucked Republican Party leaders in doing so. One of eight Iowa congressional districts at the time, the Third District was located in north central Iowa and contained 14 counties: Black Hawk, Bremer, Butler, Cerro Gordo, Chickasaw, Floyd, Franklin, Grundy, Hardin, Howard, Marshall, Mitchell, Tama, and Worth. Four counties-Black Hawk, Cerro Gordo, Marshall, and Floyd-included industrial areas with a considerable labor vote. The district contained two cities, Waterloo (pop. 65,198) and Mason City (pop. 27,980), with Waterloo being the major manufacturing center. Two of the city's largest firms were Rath Packing Company, a multiline meatpacking company, and John Deere, the tractor manufacturer. The city also served as an important railroad center for the Illinois Central. Mason City contained a cement company as well as a meatpacking firm and numerous smaller companies. Smaller cities and towns in the district served as retail trade centers for their surrounding rural populations. ${ }^{10}$

Incumbent Gwynne enjoyed several advantages. He was the dean of the Iowa congressional delegation, having served seven terms. Furthermore, times were good; in 1948 Iowa was still enjoying the strong agricultural economy that had been generated during World War II. Iowa farm families had produced record-breaking harvests between 1941 and 1945, each year producing larger crop yields and more livestock than the year before. For these and other reasons, Gwynne was widely regarded as "invincible." 11

At the same time, Gross's own support was seen as somewhat suspect; shortly before the primary, the Des Moines Register referred to Gross as "an enigma in politics. Nobody ever

10. Louviere, "The House is Losing," 26. The Third District was redrawn in 1961 when Iowa's eight districts were reduced to seven and District Three was enlarged from 14 counties to 16 . Four additional counties - Winnebago, Hancock, Wright, and Hamilton - were added, while Marshall and Tama counties were moved out of the district. Iowa Official Register, 1961-62; A Report of the Seventeenth Decennial Census of the United States, Census of Population: 1950, Number of Inhabitants (Washington, DC, 1952), I-15-8.

11. Dorothy Schwieder, 75 Years of Service: Cooperative Extension in Iowa (Ames, 1993), 101, 127; Butler, “Study of H. R. Gross,” 45. 
knows where he'll get votes." Apparently, the Register meant that it was difficult to pigeonhole Gross on issues. Although he was running in the Republican primary, some state Republican officials had again branded him as a "radical leftist." For his own part, Gross believed that he enjoyed several important advantages. In an interview with the Register, he explained that his voice "was still familiar to radio listeners in the area" and that his name was widely known among district voters. ${ }^{12}$

Gross's voice may indeed have been familiar to Third District voters, but such familiarity did not always translate into political support. Area newspapers ran editorials reflecting a favorable view of Gwynne and a dislike for Gross. In a short but clearly anti-Gross editorial, the Reinbeck Courier predicted that Representative Gwynne "would still be in the race when it was over." The editorial added that voters had rejected Gross in his 1940 gubernatorial primary campaign; "now Gross is asking for another dose of the same medicine." The editor of the Grundy Register noted that "Iowa voters were warmed [by Gross's voice over the airwaves] but they were left with a chill when he tried to speak to them from a platform." Such sentiments extended even beyond the Third District. The Manchester Press, a newspaper in northeastern Iowa, also opposed Gross's candidacy, stating that Gwynne was "one of the ablest and most popular members of the Iowa delegation," and "a man of [much] prestige and influence." 13

Although Gwynne enjoyed general popularity in the district, Gross benefited from the labor situation there. The Third District had a significant labor presence; in Waterloo, the C.I.O. was organized at both the Rath Packing Company and the John Deere plant, and each firm had about 6,000 employees. The A.F. of L. was also organized in the area. Two recent events had strained the unions' relationship with Representative Gwynne. The previous year, 1947, Gwynne had supported the Labor-Management Relations Act, more commonly known as the Taft-Hartley Act, which had challenged a number of labor union prerogatives.

12. Des Moines Register, 6/4/1948; Robert E. Bauman, “H. R. Gross: The Taxpayers' Favorite Mr. 'No,'" Human Events, 7/22/1969, 9, in Press Relations, 1949-1974, box 93, Gross Papers.

13. Reprinted in the Waterloo Courier, 11/4/1948. 
Then, during a subsequent labor strike at Rath, rioting and the death of a picketer had prompted Republican governor Robert D. Blue to dispatch the National Guard to the Waterloo plant on May 20, 1948, only days before the primary. According to the Register, both of these actions angered organized labor, making it determined to defeat Gwynne. Gross believed that any candidate opposing Gwynne would win the labor vote, and he also counted on the Iowa Farm Bureau Federation and the League of Women Voters to secure a high turnout, believing that would be to his benefit. ${ }^{14}$

Gross prevailed by a surprising 56 to 44 percent margin in the party primary. As expected, he benefited from "an angry labor vote" against Gwynne, and he was also assisted by a wave that produced a number of upsets. Along with seven-term congressman Gwynne, voters ousted the incumbent Republican governor, Robert D. Blue, and two incumbent Republican state legislators (one the Republican House floor leader) from Black Hawk County. ${ }^{15}$ The day after the election, a Waterloo Courier editorial stated that voters were in a mood for change, and that they were not willing to wait for the fall election. The editorial also noted that the "revolt against office-holders was particularly strong in the Third district and Black Hawk county." In the same edition, a Courier article noted that "Black Hawk county's Republican 'old guard' was still reeling Tuesday from the effects of a political explosion" in the primary. Given these sentiments among the Republican rank and file, it seems that 1948 was a good year for Gross to challenge a Republican Party insider. Gross was magnanimous in victory. "This is not a personal victory," he said. "It is a victory for you citizens of every walk of life in Iowa's Third congressional district." 16

In the November general election, Gross defeated the Democratic candidate, Parkersburg publisher Dan J. Ryan, by a vote of 80,030 to 58,076 (58 percent to 42 percent). As with the pri-

14. Des Moines Register, 6/4/1948; Butler, "Study of H. R. Gross," 46; Personal, 1930-1979, and General, 1955-1975, box 82, Gross Papers; Des Moines Register, 11/5/1961; Sgt. 1st Class Carolyn Tenney, "History of the Iowa National Guard," www.iowanationalguard.com/Museum/IA_History/State_Service.htm.

15. Waterloo Courier, 6/8/1948.

16. Ibid. 
mary, the fall campaign and election took a few unusual twists and turns. In what the Courier would call a race with "many odd features," local C.I.O. members gave substantial support to Gross, while some GOP leaders supported Democrat Ryan during the campaign. The state Republican Party's antipathy toward Gross, evident earlier in his 1940 challenge to the Republican governor, had continued as many Iowa Republican leaders still saw Gross as "an outsider." Similar sentiments existed among the party's rank and file. An October story in the Courier explained, "Some of the district's Republicans have said they are going to vote for Ryan. ... This is on the theory that it would be easier to defeat Ryan than Gross two years hence." Additional opposition came from out of state. Perhaps pursuing a similar logic, the conservative Chicago Tribune endorsed Ryan, sounding the by now familiar warning that Gross harbored "leftist tendencies." 17

AS A CONGRESSMAN FROM IOWA, Gross was entering an electoral environment that was highly favorable for a Republican. As historian Leland Sage has pointed out, with the easing of the Depression in 1938, politics returned to "normal" in Iowa, which meant the return of Republican Party dominance and "its traditional control of state and local governments at every level." From 1938 to 1946, Republicans controlled the statehouse and all congressional offices except for one Senate seat held by Democrat Guy M. Gillette, elected in 1938. Harry Truman did carry the state in 1948, but by 1950 all U.S. congressmen and senators from Iowa were Republicans. ${ }^{18}$

With five consecutive successful campaigns, by $1958 \mathrm{H}$. R. Gross was a proven vote getter for the Iowa Republican Party. Two years earlier, he had received the third-highest winning margin, 59 percent, among the eight victorious Iowa congressional candidates. That did not mean that Gross had won the favor of the Republican Party. He was a consistent critic of the Eisenhower administration, and that proved jarring to state party officials. Gross was particularly critical of Eisenhower's

17. Waterloo Courier, 11/3/1948, 10/17/1948; Bauman, "H. R. Gross," 9.

18. Leland Sage, A History of Iowa (Ames, 1974), 318. 


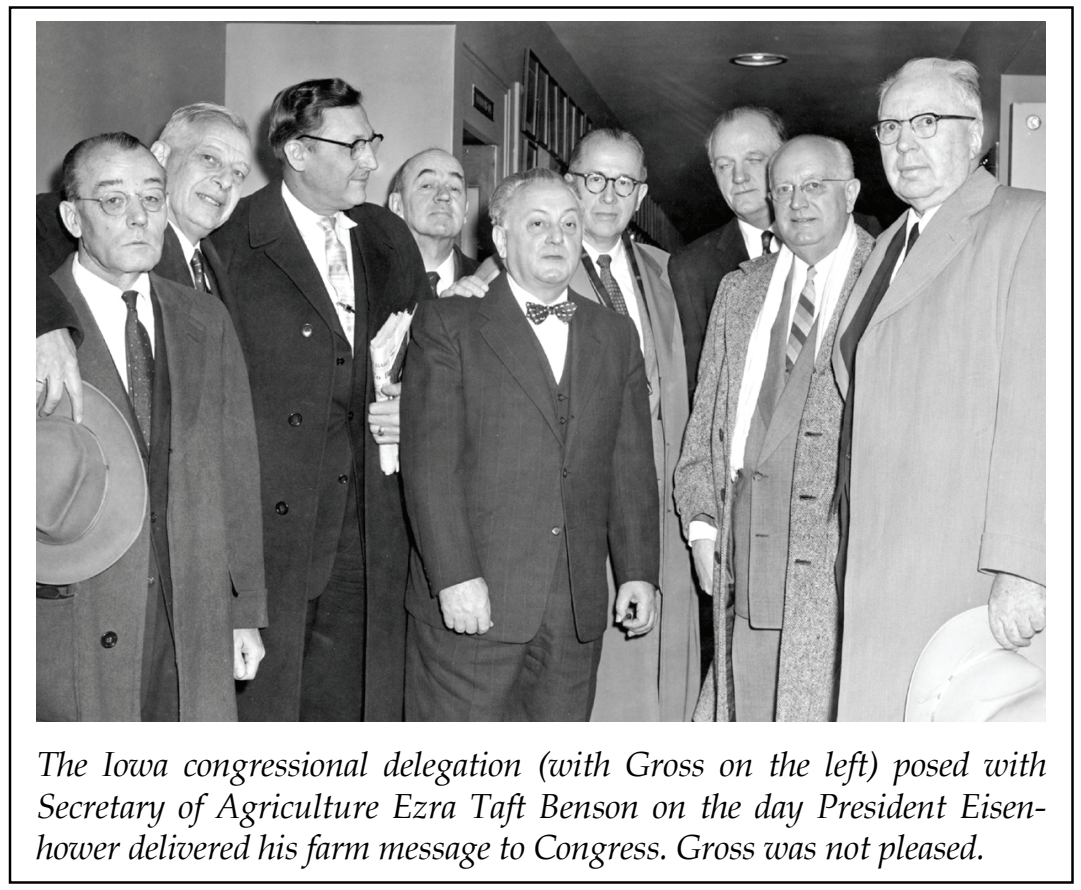

farm program, and of the president himself for retaining Secretary of Agriculture Ezra Taft Benson in the face of Republican congressional criticism. When Eisenhower responded that "those who head the various executive departments, once having been appointed, are no longer the concern of Congress," Gross accused the president of "treading dangerously close to autocratic rule." 19

Against this backdrop, state Republican officials must have found Gross's electoral success rather confounding; indeed, one source described these officials as both "aghast and amazed" at Gross's vote-getting skills. Perhaps reflecting that sentiment, Gross was the only Iowa congressman to face primary opposi-

19. Des Moines Register, 5/14/1958; weekly newsletter, “On the Capitol Firing Line," final versions (hereafter referred to as NL), numbers 181, 196, 419, 422, 428, box 97, Gross Papers. Boxes 97-107 of the Gross Papers contain a complete set of newsletters. Gross's closest call came in the Democratic landslide of 1964, when he won re-election by only 419 votes. However, that victory actually showed his relative electoral strength, since he was the only Republican congressman from Iowa returned to Washington that year. 
tion in 1958. His opponent was Enid Robinson of rural Hampton. Robinson, a graduate of St. Olaf College, had been a teacher before her marriage to a Hampton area farmer, William L. Robinson Jr., who came from a politically prominent family; his uncle, T. J. B. Robinson, had previously served in Congress. Enid Robinson was a well-known Republican Party figure in her own right; she had served six years as the party's Third District vicechair and four years as state vice-president. She was also active in 4-H and women's club work. ${ }^{20}$

Robinson apparently saw Gross as politically vulnerable on several fronts, and she argued that he had failed to successfully represent two key constituencies in the district: farmers and industrial workers. In what the Des Moines Register labeled as a "key speech," Robinson said, "I believe that the farmers of the third district are too smart to be ignored, too important to be handicapped by negative representation in Congress. I have a good idea of what our congressman is against-but I'm in the dark as to what he favors." Robinson's appeal to farmers was probably bolstered by the state of the agricultural economy in Iowa; while the postwar farm economy had been strong when Gross was first elected in 1948, demand for farm products and farm income had begun to drop by 1953, and what was described as "the farm problem" had begun to emerge in the form of agricultural surpluses, lower farm prices, lower farm incomes, and higher farm costs. ${ }^{21}$

Robinson's decision to oppose Gross was probably also influenced by the congressman's strained relationship with labor. Although Gross had managed to maintain the confidence of farmers - and would continue to do so throughout his congressional career - his honeymoon with unions had lasted for only a short time, and he faced considerable labor opposition as early as the election of 1950. In 1956 the president of the United Auto Workers of America local in Waterloo wrote, "Mr. Gross was an improvement over John Gwynne," Gross's predecessor, "but that isn't saying much on his behalf." It seems that any initial ambiguity in Gross's labor views had dissipated to reveal a more

20. Butler, "Study of H. R. Gross," 51; Des Moines Register, 5/14/1958, 5/28/ 1958.

21. Des Moines Register, 5/14/1958, 4; Schwieder, Cooperative Extension, 134. 
traditional Republicanism in that area; evidently, his populist leanings extended only to agriculture. For her part, Robinson courted unions by declaring, "The labor man is the important part of any economy. Legislation that protects the interests of the working man is desirable." 22

A Robinson campaign ad that asked "Why be 'Gross-ly' Confused?" listed six reasons to support Robinson: sound labor and farm programs, the encouragement of world peace and world trade, the claim that she was a "full time Republican," and the need for a positive approach in representing the Third District. Although Gross stressed his experience and included laudatory comments from two fellow members of the House in his advertising, Robinson also ran on the claim that Gross was unpopular with other members of the House and was, therefore, an undesirable representative. Those themes reflected long-standing party antagonisms. Party loyalists saw Gross as disruptive and disloyal-most obviously in the claim that he was not a "full time" Republican-but also in the suggestion that he was at odds with other Republicans in the House. Moreover, Robinson's promise to provide a positive approach clearly, if implicitly, painted Gross as being negative in his own approach and style. ${ }^{23}$

Yet another interesting subtext in the race involved the nature of the national Republican Party in the 1950s. A traditionalist Republican faction, mostly centered in the Midwest, favored a smaller federal government and abhorred much New Deal legislation. The other wing of the party, chiefly located in the East, supported a somewhat larger, more activist state. The two camps were particularly divided over the degree of internationalism that was desirable in postwar foreign policy. In most respects, Gross's views placed him at least in the general vicinity of the traditionalist camp, while Robinson's advocacy of world peace and world trade suggested that she was following the eastern faction's more progressive lead. This national party division played itself out in Iowa's Third District Republican race. ${ }^{24}$

22. Letter from Gene Condon, U.A.W. Local 838, C.I.O., 5/16/1956, quoted in Butler, "Study of H. R. Gross," 75; Des Moines Register, 5/14/1958.

23. Waterloo Courier, 6/1/1958; Kansas City Star, 7/12/1958.

24. James T. Patterson, Mr. Republican: A Biography of Robert A. Taft (1972), chaps. 17-19. 
Although the consensus among state Republicans held that Robinson had run a good race, Gross defeated Robinson in the June primary by garnering 52 percent of the vote. ${ }^{25}$ The 1958 primary turned out to be something of a watershed in the relationship between Gross and the Iowa Republican Party. Gross faced little if any primary opposition after 1958. Apparently, the state party, if it did not exactly embrace Gross's maverick ways, at least learned to accept them. The seeming rapprochement was probably further facilitated by the election of 1960, when Eisenhower left office and John F. Kennedy inaugurated an eight-year span of Democratic control of the presidency. Gross would continue to criticize presidents, but for the foreseeable future his attacks would no longer represent a divisive force among Republicans. ${ }^{26}$

BY 1958, Gross's maverick image, long familiar to Republican regulars, had also become well established throughout Iowa, supplementing the recognition that had come from his earlier farm advocacy work. Moreover, the congressman was also developing a national reputation. In an article profiling Gross that ran in the Kansas City Star in July 1958, a month after his primary victory, a reporter wrote that the Iowan had no intention of "treading the primrose path to influence among his colleagues." The reporter portrayed Gross as a "lone wolf" who opposed what he viewed as improper spending bills, regardless of how his actions might infuriate his colleagues. ${ }^{27}$ Other publications repeatedly echoed much the same sentiments, commenting on Gross's independence, his obvious disregard for colleagues' opinions, and his seeming immunity to criticism and ridicule. ${ }^{28}$ Once in Congress, Gross had earned the image of a hard-working, straight-talking, independent, and frugal lawmaker, and that portrait would prevail throughout the rest of his career. His emphasis on fiscal prudence, while valuable in its own right,

25. Des Moines Register, 6/3/1958.

26. Ibid.

27. Kansas City Star, 7/12/1958.

28. See, for example, Des Moines Register, 11/5/1961; and Jacques Leslie, “H. R. Gross: The Conscience of Uncle Sucker," Washington Monthly, August 1971. 
also served to effectively distance him from association with the sorts of radical measures that he had supported in the 1930s.

At the same time, Gross's early congressional career offered a clear view of another fundamental facet of his style: his habitual pessimism about America. After two years in the House, Gross sat for a radio interview with NBC News in Washington, D.C. Gross was asked: "What in your opinion is the outlook for the people of the world in general and the United States in particular in the weeks and months to come?" He reeled off a litany of problems facing the United States, including high unemployment, a decline in national income, and a drop in farm income. He believed that the country had tried to solve every problem at home and abroad with money; that approach had put the United States in a "rat race" that he believed could only end in "an economic crackup or World War III." Gross's concern for agriculture was clearly evident, as over one-third of his radio comments related to the recent drop in agricultural prices and the difficulties facing Iowa farmers; he also touted the "cost of production farm bill," which he had introduced into Congress two months before. That radio interview featured not a single positive comment about current or future conditions in the country. Gross ended the interview the same way he would later end many of his constituent newsletters, with a story: "To sum up and try to answer your question, the outlook for the world in general and for our country in particular is very much like the man who fell from the window of a 25 story building. When he passed the 10th floor he was heard to say, 'I'm all right - so far!'" Such persistent pessimism was evident to others; a magazine feature article would later describe Gross as "preaching impending Apocalypse like a backwoods circuit rider." 29

CLEARLY, Gross was good at winning elections, even though he seemed to lack some characteristics commonly associated with political success. Why did he do so well? Most broadly, he was aided by several general factors. He had gained broad recognition in his radio broadcasting days, and Iowa was heavily

29. Leslie, "Uncle Sucker," 36; "Coffee in Washington," NBC Radio Program, 5/6/1950, Speeches, 1949-74, box 95, Gross Papers. 


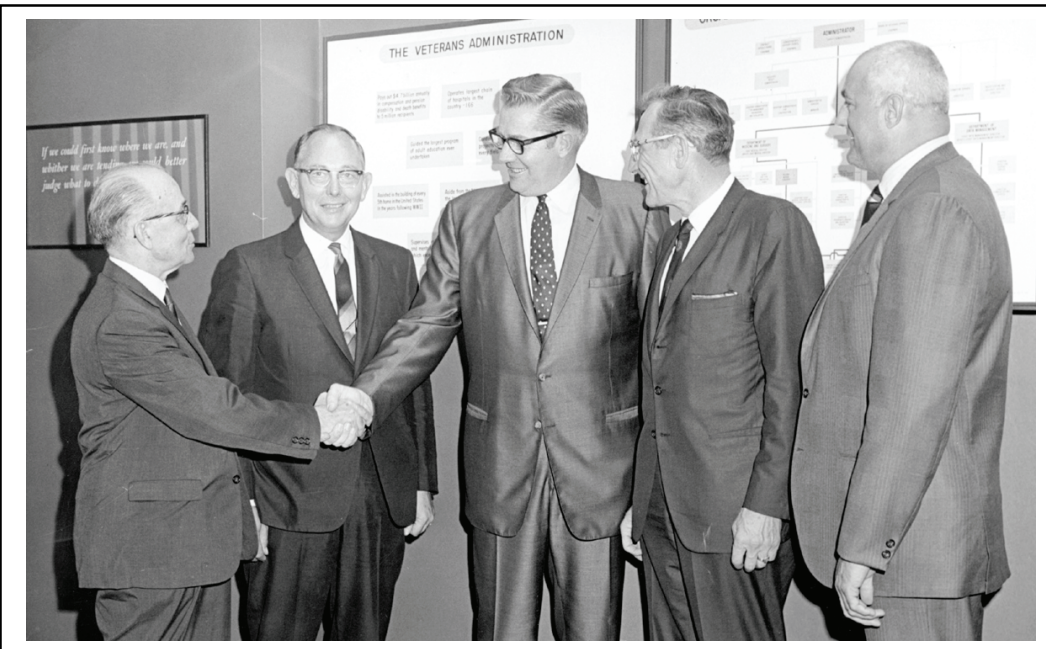

Congressman Gross congratulates Donald E. Johnson of West Branch, Iowa, on his appointment as administrator of the Veterans Administration, the largest independent agency in the federal government. Johnson was a prominent Iowa farm supply executive, World War II Army combat veteran, and national commander of the American Legion. Standing between Gross and Johnson is Iowa Senator Jack R. Miller, with Iowa Representatives Fred Schwengel and William J. Scherle to Johnson's left.

Republican during the crucial early years of his congressional career. Once in office, Gross also benefited from his incumbency; House re-election rates ranged around 85 to 90 percent during his tenure in Washington. Moreover, he also worked hard to ensure his own success.

Congressional scholars have noted that House members have multiple constituencies. Gross used various means to cultivate different groups in his district. Early in his House career, he began publishing a weekly newsletter titled "On the Capitol Firing Line." Sometimes with humor, but more often with sarcasm and scorn, Gross wrote about political issues in Washington, pending House legislation, and his views on various political figures. He often criticized presidential administrations, both Democratic and Republican, but he reserved his greatest ire for spending legislation and the ever expanding national debt. Readers soon learned that each issue contained large doses 
of Gross's personal political philosophy as well as summaries and discussions of national political issues. Unlike other members of Congress, Gross wrote the newsletter himself. The Des Moines Register reported that "he isolated himself in his office every Friday to write it for release the following Wednesday." Office staffers mimeographed and printed each issue on a legal size sheet of paper; typically, each issue ran about 600 words. By 1956, the newsletter's circulation was over 2,600. According to an administrative aide, the newsletter was mailed to party leaders in his congressional district, newspaper editors, and "constituents who request it." The aide also noted that Gross was the only congressman who sent out a regular weekly newsletter. Some other congressmen had newsletters, but they were published only while Congress was in session or during election years. The newsletter also appears to have been of relatively high quality; in 1965 House Speaker Joseph Martin said that Gross's newsletter was one of the best to be published by a member of the House. 30

Gross, like all members of Congress, communicated with voters in a variety of ways, but the newsletter probably provided the most direct and consistent link. Week after week it connected him to much of his core constituency in the district, repeatedly reminding them of the myriad ways their congressman was working on their behalf in Washington, and giving Gross a chance to speak his own mind in an unmediated manner. As a former journal editor and newscaster, Gross understood the power of words as well as the most effective ways to frame issues. He used many stock phrases and emotionally laden terms, and his writing was clear, direct, and often repetitive. His style helped readers understand his positions, an understanding no doubt aided by the fact that those positions rarely

30. David C. Huckabee, "Reelection Rates of House Incumbents: 1790-1994," Congressional Research Service Report 95-361 (1995), at www.thirty-thousand .org/documents/huckabee2.pdf; Richard F. Fenno Jr., Home Style: House Members in Their Districts (Boston, 1978), 27; Des Moines Register, 12/19/1974; Butler, "Study of H. R. Gross," 62; Memo from Joseph Martin to Clare Boothe Luce in Correspondence, Congress Members, box 2, Gross Papers. Some of the early newsletters were longer, but by mid-1951, each newsletter was one page, legal size. 
changed. Furthermore, Gross's sarcastic humor probably left many readers with a chuckle or two.

Each newsletter covered a variety of issues, but over the course of its 26-year run, certain topics appeared with particular regularity, including the United Nations, foreign aid, agricultural parity, the Peace Corps, the national debt, and salary increases for members of Congress and other federal officials. Surprisingly, the newsletter contained few references to major political events between 1948 and 1974, such as Joseph McCarthy's anti-Communist crusade or the Watergate scandal. During the first year or two, Gross occasionally referred to labor issues and labor legislation, but he rarely mentioned those topics after 1950. Discussion of economic issues often dominated the newsletters. ${ }^{31}$ Whether writing about reckless government spending, wasteful political junkets, or lavish entertainment expenses, Gross not only informed voters about what he saw as unnecessary expenditures, he also clearly positioned himself as an opponent of those measures. He peppered the newsletters with his favorite nicknames for public programs that he saw as wasteful or otherwise flawed. The Pentagon was "Fort Fumble," a label meant to disparage its allegedly profligate usage of tax money, and he called NASA's lunar landing program a "moondoggle." Gross seemed to take particular delight in lambasting the Peace Corps, which he believed was nothing more than a haven for draft dodgers, and he frequently criticized the United Nations, calling it the "Tower of Babel." In Gross's view, all foreign-aid programs, including the Marshall Plan, were simply giveaways of Americans' hard-earned money. And he had total scorn for government funding of any arts or humanities programs, believing that such efforts ought to be paid for privately. Summarizing his views, Gross often referred to Uncle Sam as "Uncle Sucker" or "Uncle Sap." 32

31. Most issues of the newsletter contained some comments regarding unnecessary government spending or the poor condition of the U.S. economy. See, for example, NL 17, 41, 49, 100, 105, 118, and 303.

32. For examples of the prevalence of economic discussions, see NL 17, 42, 49, 65, 99, 100, 106, and 303; for the Peace Corps, 1030; United Nations, 65, 106, and 120; foreign aid, 98, 102, 119, and 531. Examples of frequent references to Uncle Sam as Uncle Sucker or Uncle Sap are in NL 263 and 529. 
Letters sent to the congressman indicate his constituents' admiration for his direct style and frugality. Cedar Rapids resident Nancy C. Zook wrote Gross in December 1964: “We like your plain talk, your down-to-earth expression of just what under the sun is going on in Washington and elsewhere. We need more men like you." In September 1971, Maude and Stone Linstrum's letter touched on another popular theme: "You have certainly worked hard to prevent reckless spending of taxpayers' money." Ding Darling, the popular Des Moines Register political cartoonist and conservationist, was another Gross fan. In February 1960, he wrote, "I notice with pleasure that you are up for re-election. I wish I lived in your District so that I could vote for you. If we don't stop the wage spiral and the consequent inflation now I'm afraid we will pass the point of no return." 33

Along with issues and public policies, the newsletters often took square aim at a variety of political figures. Eleanor Roosevelt, for example, became "Lady Bountiful" because she was supposedly so bountiful with other people's money. Gross criticized the policies of all the presidents who served during his congressional tenure, but he reserved special scorn for Democrats, especially President Harry Truman. Gross leveled strong, sometimes biting criticism at Truman's foreign and domestic policies, and he also seemed to personally dislike the president. During Truman's time in office, Gross repeatedly called him the "Pendergast-trained Truman," referring to his prior association with the Pendergast political machine in Kansas City. In one newsletter, Gross described the Truman regime as "shot through with corruption"; in another, he alleged that Truman "lived like a king." On various occasions, Gross criticized Truman's actions in Korea. At one point, he referred to the Korean War as "Operation Killer." Gross acknowledged that the United States was opposing the Chinese Communists, but he wrote that the "youth of America [are] being slaughtered, too, and what is the objective? We're still waiting for the Pendergast politician to tell us." Gross believed that a number of Truman's domestic economic policies, enacted in response to the war, had led toward a con-

33. Correspondence, 1948-1975, box 20, Gross Papers; Ding Darling, People, box 79, Gross Papers. 
trolled economy and came "dangerously close to totalitarianism." Even after Dwight Eisenhower became president, Gross continued to criticize Truman for his "big spending." 34

John and Jacqueline Kennedy were also frequent targets of Gross's scorn. Gross particularly seemed to enjoy poking fun at what he described as the couple's "high living" lifestyle. To Gross, the Kennedys epitomized the Washington social elites he seemingly despised. At various times he referred to the "black tie and monkey suit atmosphere" and to the "striped pants crowd." Gross also expressed great concern about the expense of Kennedy's inauguration and the costs of creating what would become the Kennedy Center for the Performing Arts. Following Kennedy's assassination, he opposed giving his widow a government pension, cracking that "she certainly doesn't need it"; and in a maneuver once described as "the single most heroically curmudgeonly act in the history of Congress" he stood on the floor of the House and argued against placing an "eternal flame" at JFK's gravesite in Arlington National Cemetery. His rationale? Because the natural gas needed to fuel it would cost too much. ${ }^{35}$

Tirades against the Kennedys and others also allowed Gross to charge that Washingtonians drank too much alcohol, abetted by what he called the federal government's "booze allowance." Beyond attacking disliked elites, tactics such as this allowed Gross to contrast the behavior of wealthy Washingtonians with that of ordinary, hard-working - and, presumably, abstemious - folks from Iowa, character traits Gross presumably applied to himself as well. Gross disliked any display of pretentiousness and often pointed out that he and his wife lived a quiet, simple life. He noted with some pride that his wife had never owned a ball gown, nor had he ever owned a tuxedo. The couple typically spent evenings at home, where $\mathrm{H}$. R. read bills or other

34. NL 581, 586, 116, 21, 71, 66, 181.

35. NL 579, 584; Bauman, "H. R. Gross," 9; Bill Kauffman, “The Eternal Flamethrower," The American Enterprise, November/December 1999, n.p. Gross later refuted the claim that he had opposed the "eternal flame," arguing that his remarks had been misunderstood. See Campaign Memo \#2, 1964 Campaign (3rd Congressional District-Iowa), Literature and Advertisements, box 87, Gross Papers. 


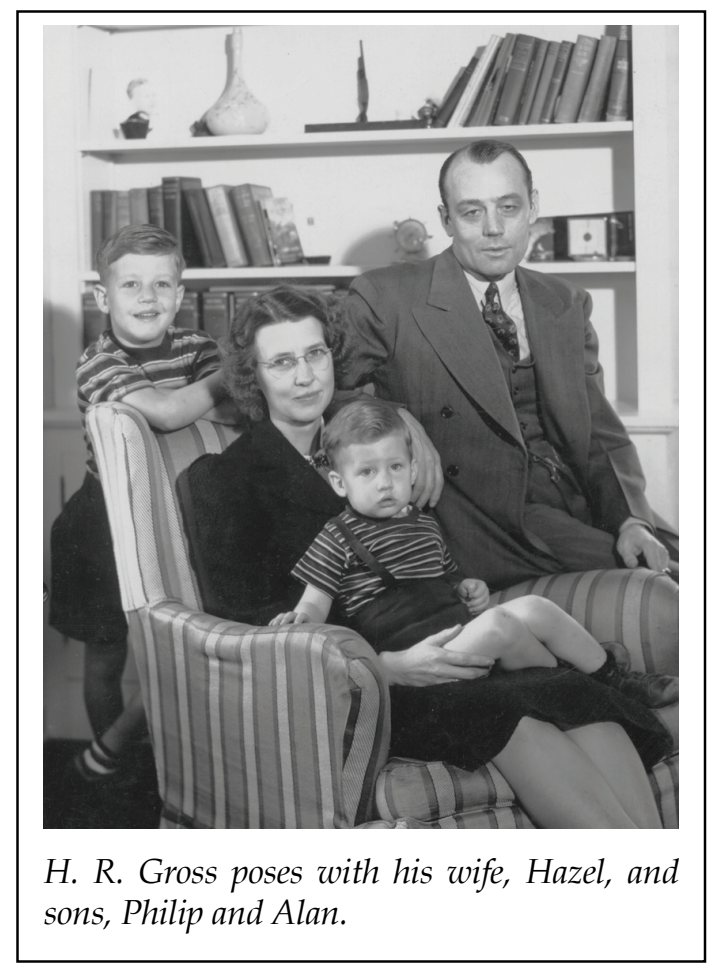

material relevant to House legislation, and his wife, Hazel, circled articles that might be of interest to her husband. Sometimes the couple indulged in a few games of cribbage before bed. 36

Many of Gross's writings showed a decidedly populist cast, harking back to the late nineteenth century, when Populists had condemned eastern financiers' conspiratorial behavior and control of the country's economy. ${ }^{37}$ Gross often lambasted wealthy

36. Louviere, “The House,” 29; Des Moines Register, 11/5/1961; NL 150.

37. Populism was a movement in the late 1880s and 1890s that involved farmers, laborers, and reformers who believed that rapid technological change had benefited industrialists and financiers but had drastically hurt the economic interests of farmers and laborers. Such views were first manifested in various farmers' alliance organizations. Before long, however, the Populist Party, a short-lived third party, became most visible in representing these views. The term populist has since become part of Americans' political vocabulary and is often used to describe people who claim to represent the interests of ordinary Americans as opposed to economic and political elites. See "Populism," in Dictionary of American History, ed. Stanley I. Kutler, 3rd ed., 10 vols. (New York, 2003), 6:416-18. Other standard sources on Populism include John D. Hicks, 
easterners, criticizing their influence in government and the money they spent on "lavish" entertaining. One of his favorite terms of derision for the wealthy was "the fat boys." He contrasted the financial concerns of ordinary Iowans-such as the March 15 income tax deadline-with what he described as "plush affairs" in Washington, such as the Democrats' JeffersonJackson Day dinner, where tickets cost $\$ 100$ per seat. Gross often reminded his readers that he was on their side. He portrayed himself as standing up for small business and the "little man," protecting them from wealthy easterners and a federal government that often sought to pick the pockets of ordinary folk. ${ }^{38}$

WHILE GROSS'S NEWSLETTERS connected him with an important core constituency, his broader contacts with Third District residents were another key part of his continued political success. Gross was particularly adept at paying attention to individual voters. When he returned to his district, he rarely delivered major speeches, opting instead for conversations with individual Iowans. Apparently it was not unusual for Gross to interrupt a farmer in his fields, seeking his views about agriculture and farm issues. Gross also served individual voters by reading and answering all letters promptly, believing that no request was "too small or inconsequential for his attention." And his replies were no mere form letters: until at least 1971, he apparently sent personally written replies. His prompt, personal replies to hundreds of constituents paid dividends on election day. One area newspaper editor wrote that Gross "has done so many little favors for so many little people that he would be extremely difficult to defeat in either a primary or a general election." Gross never strayed far from his voter base, whether traveling in Iowa or serving in Washington. ${ }^{39}$

The Populist Revolt: A History of the Farmers' Alliance and the People's Party (Minneapolis, 1931); Lawrence Goodwyn, Democratic Promise: The Populist Moment in America (New York, 1976); Robert C. McMath, Jr., American Populism: A Social History, 1877-1896 (New York, 1993); Jeffrey Ostler, Prairie Populism: The Fate of Agrarian Radicalism in Kansas, Nebraska and Iowa (Lawrence, KS, 1993); and Michael Kazin, The Populist Persuasion: An American History (New York, 1995).

38. NL 10, 63, 65, 73.

39. Quoted in Butler," Study of H. R. Gross," 65. 
Such efforts to stay connected with voters were especially important since Gross was not active in bringing federal programs and spending back to his district. There were exceptions, however. In October 1958 Gross issued a press release announcing that the Post Office Department was to expand rural mail delivery service, and that approximately 3,500 farm families in the Third Congressional District would benefit from the change. He also noted that he had long pushed for the development. Shortly thereafter, he also announced that he had recommended that the Post Office Department conduct surveys in Sumner and La Porte City "with a view to establishing city carrier service" in those towns. Upon completion of the surveys, postal officials in both communities began home mail delivery. Such activities were evidently not the norm for Gross, however. Despite the obvious political benefits of pursuing constituency "pork," Gross seems to have remained essentially faithful to his underlying philosophy of fiscal conservatism. ${ }^{40}$

Political scientists Paul Karps and Heinz Eulau argue that members of Congress engage in several forms of representation: allocative representation (securing allocations of federal programs and services), service representation (doing casework and other favors for constituents), and symbolic representation (representation involving public gestures that create a sense of trust between members and constituents). That framework illuminates the approaches used by Gross. Although he largely eschewed allocative representation, doing little to secure federal benefits for the Third District, he devoted substantial attention to providing constituent services, and his diligent efforts to position himself as a champion of the people clearly involved a strong element of symbolism. ${ }^{41}$

40. Press Release, Press Relations, 1949-1974, box 94, Gross Papers. Gross started his policy of fiscal responsibility early in his career, and Iowa newspapers were quick to take note of it. In September 1951, the Traer Star-Clipper ran an editorial praising Gross for objecting to $\$ 19$ million (in a $\$ 6$ billion military spending bill) for the construction of an airport at Grandview, Missouri. Although his effort failed, other Iowa newspapers in Des Moines, Cedar Rapids, Marshalltown, and Waterloo all hailed Gross's efforts at cost-cutting. See Congressional Record 97, 82nd Cong., 1st sess. (Washington, DC, 1951), A5581.

41. Heinz Eulau and Paul D. Karps, "The Puzzle of Representation: Specifying Components of Responsiveness," Legislative Studies Quarterly 2 (1977), 241. 
Finally, Gross also benefited from generally favorable treatment by the media. Most newspapers in the Third District supported Gross. Some, notably the Traer Star-Clipper, offered unqualified support, while others, such as the Eldora Herald-Ledger, supported the congressman with reservations. Herald-Ledger editor George R. Stauffacher wrote, "We have less of a rubber stamp Congress because of men like Gross and this is always a healthy condition in politics." A few papers were generally critical, most notably the Mason City Globe-Gazette, one of five dailies in the district, whose editor, Earl Hall, had a longrunning feud with the congressman. Editors of both the Osage Press-News and the St. Ansgar Enterprise criticized Gross for his negativism and his supposedly poor committee assignments. ${ }^{42}$

Earl Hall was Gross's strongest and most tenacious critic. On December 2, 1954, he wrote a particularly hard-hitting editorial, listing ten reasons why Gross was unfit to represent the Third District. Gross, he said, was a "lone wolf" who had no personal friends, possessed no personal warmth, had difficulty obtaining recommendations from radio stations or newspapers where he had been employed, had been "savage" in his criticism of President Eisenhower, and was shunned by other Iowa congressmen. Following this lengthy recitation of grievances, Hall lamented the lack of a credible contender who could successfully challenge Gross. ${ }^{43}$

A 1958 Republican primary endorsement by the Hampton Chronicle took a more typically positive tone toward the congressman. Indeed, the endorsement was notable in this regard, as Gross's primary opponent, Enid Robinson, was from rural Hampton, and thus the Chronicle was her hometown paper. As reporter George Mills pointed out in a Des Moines Register article at the time, county-seat newspapers typically either supported a local candidate or remained neutral. Explaining the endorsement, Chronicle editor Dwight Purcell said the paper backed Gross simply because he was the better candidate. ${ }^{44}$

42. Quoted in Butler, "Study of H. R. Gross," 85, 86.

43. Mason City Globe-Gazette, 12/2/1954.

44. Des Moines Register, 5/28/1958. 
AS THE DISCUSSIONS of his background and "home style" suggest, Gross's fiscally conservative philosophy was firmly established by the time he reached Washington. While he manifested a general disdain for government spending, with the exception of agricultural appropriations, the main objects of his opposition were the same programs that he railed against in his newsletter. He was especially opposed to foreign aid, pay raises for legislators or other government workers, and foreign junkets by colleagues. His opposition to the latter was so persistent that junketing colleagues took to sending him postcards from their various far-flung destinations, often expressing some form of the sentiment, "Wish you were here!" Besides his disdain for fiscal imprudence, he also focused on other matters that might be seen as involving government abuse, including any selfserving arrangements among congressmen, and scandals such as the ones involving Representative Adam Clayton Powell, Lyndon Johnson associate Bobby Baker, and U.S. Supreme Court Justice Abe Fortas. ${ }^{45}$ In general, one might say that Gross opposed impropriety, fiscal or otherwise.

Gross advanced his legislative priorities through a distinctive legislative style. Perhaps most fundamentally, he devoted a striking level of effort to his job. He attempted to read all bills that made it to the House floor, a daunting task, given the number and length of those bills. As a result of his diligent reading of bills, most of which took place in the evening, at home, after the daily legislative session had ended, he generally had advance notice of the nature and details of upcoming legislation, and often a better understanding than most of his colleagues had. He devoted a similar level of effort to actual House legislative sessions; he was known for arriving early and staying late. The picture that emerges is of an active legislator, verbally engaged and frequently in the thick of things. ${ }^{46}$

45. Leslie, "Uncle Sucker," 39, 43. The term home style is from Fenno, Home Style. 46. Many articles describe Gross's work habits. See, for example, Kansas City Star, 7/12/1958; Des Moines Register, 11/5/1961; Louviere, "The House is Losing"; Mills, "Remarkable Mr. Gross"; Norman Miller, "Iowa's Mr. Gross Wins Fame by Viewing Life With Jaundiced Eye," Wall Street Journal, 5/28/1969, in Press Relations, 1949-1974, box 93, Gross Papers. 
Furthermore, Gross expended his unusual level of effort in an unusual place. In the House, members have traditionally devoted most of their effort to committee work, which, for most Representatives, becomes the source of most of their legislative input and clout. Committee recommendations and expertise tend to carry substantial weight on the floor, and thus a members' committee work can ultimately affect legislation. Woodrow Wilson, a professor of politics before he was president of the United States, famously declared, "Congress in its committeerooms is Congress at work." 47

Gross turned that traditional approach on its head. He did serve on several committees, but he devoted most of his effort to addressing legislation in the central chamber of the House. Exercising his customary diligence, Gross spent long hours on the House floor, evidently animated by the possibility that others might try to pass expensive legislation or sneak something else through during times when most members were inattentive or absent. He even went so far as to stake out his own personal seat. In a chamber where rank-and-file members did not enjoy formally assigned seating, "H. R. Gross's seat" was located front and center, giving him a useful perch from which to monitor all activities on the House floor. An observer vividly portrayed the scene: "And there he sits, day after day, on the aisle of the Republican side near the committee table, the little Dutch boy with his finger in the dike, a solitary sentry of thrift watching the mountainous seas which threaten, he believes, to engulf the treasury." 48

47. Tim Groseclose and David C. King, "Little Theatre: Committees in Congress," in Contemplating the People's Branch: Legislative Dynamics in the TwentyFirst Century, ed. Kelly D. Patterson and Daniel M. Shea (Upper Saddle River, NJ, 2000), 204; Steven S. Smith, The American Congress, 2nd ed. (Boston, 1999), 198; Woodrow Wilson, Congressional Government (New York, 1956), 69. The House has a set of standing committees, organized by substantive areas, such as appropriations or foreign affairs. These committees formulate, revise, and review legislation before it can be considered on the chamber floor. Members are assigned to several of these standing committees - most typically to committees involving matters that are important in their districts, or where the substantive focus happens to interest them - and they then work assiduously to become experts on the committee's subject matter.

48. Louviere, "The House is Losing," 24; Des Moines Register, 11/5/1961. Gross served on the Foreign Affairs, Post Office, and Civil Service committees. 
Literally, the U.S. House of Representatives just didn't get much past H. R. Gross.

Strong parliamentary skills complemented his diligent labors. He was regarded as an effective parliamentarian, and he employed a variety of legislative tactics to advance his interests (or, one could say, to obstruct the passage of bills). One of his favorite devices was the quorum call. House rules require a sufficient number of members to be present before official business can occur. This requirement, however, is often overlooked for purposes of expediency. But if a member requests a quorum call, that request must be granted. That temporarily suspends legislative activity until the roll is called, a rather lengthy procedure in a body as large as the U.S. House. Further delay results if the chamber falls short of a quorum. The House would then either have to adjourn, or the sergeant at arms would have to go out and round up a sufficient number of members. Gross was also famous for objecting to unanimous consent decrees. In Congress, unanimous consent is used to suspend burdensome and time-consuming rules, thus allowing faster processing of routine business and noncontroversial measures. Since "unanimous" is taken literally, Gross's lone objection was enough to scuttle a decree, forcing more formal-and lengthier-floor procedures. At one point, House leaders eliminated a minor chamber procedure to prevent Gross from creating delays by invoking it. ${ }^{49}$

Such strategies suggest that Gross was not afraid to inconvenience colleagues, embarrass them, or even incur their wrath, even in a body that was generally considered collegial (at least for most of his tenure). Like most mavericks, he often objected to the usual ways of doing things. His tendency to challenge leaders and other rank-and-file members, and to object to "business as usual," sometimes caused serious difficulties and disruptions for others. One important example involved the House calendar. Many members preferred to schedule important floor business on Tuesday through Thursday, creating a long weekend, which gave members more time to return to their home

49. Walter J. Oleszek, Congressional Procedures and the Policy Process, 6th ed. (Washington, DC, 2004), 335, 339; Mills, "Remarkable Mr. Gross"; "Useful Pest," Time, 6/15/1962, 21, in Press Relations, 1949-1974, box 93, Gross Papers; Miller, "Jaundiced Eye"; Bauman, "H. R. Gross," 8. 
their home districts. Consistent with his firm personal beliefs that serving in Congress was a full-time responsibility and that members belonged on the floor, Gross often objected, forcing other members to revise their schedules and reshuffle their plans. One time he objected to a unanimous consent decree that would have allowed members to travel to Florida to see the Apollo 11 moon launch, thereby forcing the chamber to meet on that day. He proved so nettlesome to his own party leadership that House Minority Leader Gerald Ford reportedly quipped, "There are Three Parties in the House: Democrats, Republicans, and H. R. Gross." House Speaker Carl Albert once said that Gross had disrupted his plans "so many times, I can't recall." As these comments by two House leaders show, Gross had definitively rejected the advice of another House Speaker, Sam Rayburn, who had once counseled, "To get along, go along." 50

ONE MIGHT WONDER how Gross could continue to clash with the Republican Party, in elections and in the House, throughout his congressional career, without suffering serious repercussions. Simply put, Gross could be independent because he could attain his own personal goals despite his clashes with his party. What were those goals? Surveying House members in the 1960s, political scientist Richard Fenno determined that representatives generally held three goals: re-election, good public policy (as defined by the member), and personal influence in the chamber. ${ }^{51}$

Gross embraced the goal of re-election, as every member of Congress must, but he had little reason to fear that his maverick status in the party would harm him. Although political parties in many foreign countries can bar nonconformist legislators from running as party members in future elections-thus giving members a powerful incentive to toe the party line-American parties cannot control access to the ballot in that manner. ${ }^{52}$ Ac-

50. Leslie, “Uncle Sucker," 41, 42; Kansas City Star, 7/12/1958.

51. Richard F. Fenno Jr., Congressmen in Committees (Boston, 1973), chap. 1.

52. Burdett A. Loomis, The Contemporary Congress, 3rd ed. (Boston, 2000), 127. It is important to note that party leaders in the House can sanction uncooperative members in other ways. They can deny nonconformists access to valuable 
cordingly, in the United States, the party's only option is to attempt to defeat a maverick member in the party primary, as Iowa Republicans tried in 1958. However, a strong vote getter such as Gross generally had little to fear from that kind of challenge.

Within the chamber, Gross deviated from Fenno's findings: he had no desire to occupy a party leadership position or to win appointment to a prestigious committee, the usual means for achieving personal influence in the House. Absent the desire for personal position, he had no need to court the support of other Republicans. Gross himself once remarked on this: "You can't aspire to leadership and do the things I feel I must do." 53 Accordingly, because Gross's re-election prospects were secure, and because he was not interested in personal prestige, he was free to focus on his third goal: he could pursue his personal vision of good public policy - fiscal prudence and member integrity - no matter how much his actions might sometimes anger his party.

Finally, besides his other legislative resources and skills, Gross's legislative efforts were also bolstered by his personal characteristics, most notably his sharp wit and sense of humor. When his dogged efforts had identified questionable expenditures, he could level humor - or scorn - with devastating effect, often making colleagues squirm. On at least one occasion he was involved in a "Bundles for Congress" program that satirized a congressional pay raise by collecting old clothing for lawmakers, the implication being that they must have been destitute to need the extra money. Gross also had a thick skin. That is a virtueand to some degree, probably a necessity - for all politicians, but Gross seems to have been more impervious than most. That allowed him to persist in his isolated, maverick ways when more sensitive members might have buckled under pressure from party officials or the anger or dissatisfaction of peers. ${ }^{54}$

All of these factors combined to bring Gross substantial national media attention. He was featured in stories in a variety of

resources such as shared campaign funds and information on bills and other chamber activities. Gross did incur some such costs for being a party maverick, but none that he could not easily bear. Smith, American Congress, 182-84.

53. Bauman, “H. R. Gross,” 10.

54. Ibid. 
national publications, and he received many more incidental mentions. Such treatments varied in tone. Some were largely positive; others could be quite critical. Redbook magazine once listed him among the worst members of Congress, and Life counted him as a member of the "Neanderthal Right." Others dubbed him the "Abominable No-Man" in reference to his habit of voting against most bills and his general legislative obstructionism. Gross also enjoyed broad recognition among the public; a Time magazine reader from Georgia nominated him for the magazine's "Man of the Year" award in 1963. 55

Gross's physical characteristics probably contributed to his notoriety. He had a deep, booming voice and something of a distinctive appearance. Perhaps referencing his Iowa connection, one writer once compared him to the man pictured in Grant Wood's American Gothic. All of the attention he received was probably magnified by the fact that so much volume came from such a little wisp of a man; former WHO Radio colleague Jack Shelley recalled that Gross could not have been over 5'3." The press attention, while noteworthy in itself, is even more striking given that Gross served in the House. Senators typically receive far greater media attention; members of the House tend to toil in obscurity. Not H. R. Gross. ${ }^{56}$

LEGISLATIVE STYLE ASIDE, any analysis of Gross must ultimately consider the question of legislative effectiveness: simply put, did H. R. Gross succeed in his core mission of reducing, or at least restricting, federal spending? By the most obvious yardsticks, his influence would seem to have been relatively slight. He sponsored relatively few bills-a common benchmark of legislative influence-and many of the ones he did propose were symbolic or even quixotic. Every session, he introduced the eponymous H.R. 144 (cleverly named because House bills start with "H.R.," for "House Resolution," and a gross equals 12 dozen, or 144), a measure that proposed a gen-

55. "Our Worst Congressmen," Redbook, October 1952, 73, in Press Relations, 1949-1974, box 92, Gross Papers; "While Eisenhower Proposes the Old Guard Disposes," Life, 6/21/1954; Letter to the Editor, Time, 12/27/1963.

56. Ames Daily Tribune, 1/18/1974; Shelley, interview, 9/29/2006; Ross K. Baker, House and Senate, 3rd ed. (New York, 2001), chap. 5. 


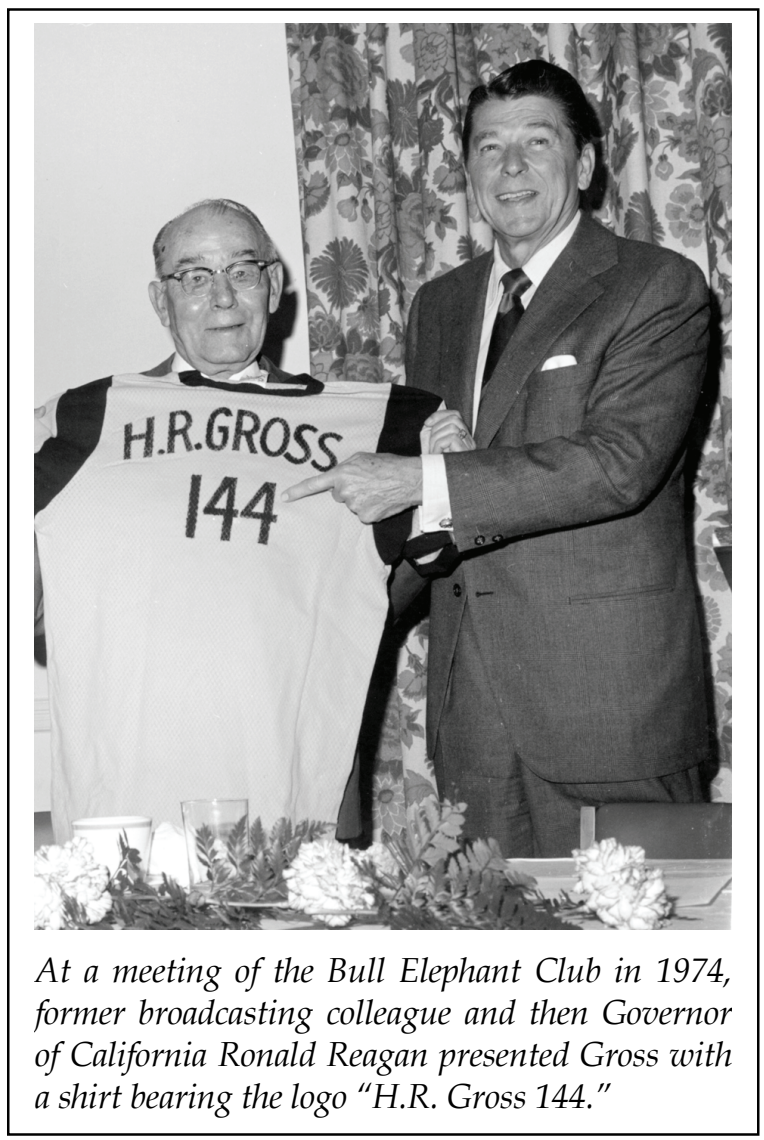

eral program of fiscal restraint. More fundamentally, House Republicans were the minority party for almost all of Gross's tenure. During his 13 terms, Republicans controlled the chamber only from 1952 to 1954. That impeded Gross's ability to sponsor or back successful legislation. Finally, Gross was truly a singular voice. Indeed, he appeared to revel in such a status; one author noted that Gross seemed to cultivate the image of a loner by choice. The status of an isolated, rank and file, minority party member is not a recipe for influence in the U.S. House of Representatives. ${ }^{57}$

57. Jude Wanniski, "With Jeers and Jests, Mr. Gross Makes His Point," The National Observer, 7/24/1967; Louviere, "The House is Losing," 26; Edward V. Schneier and Bertram Gross, Congress Today (New York, 1993), 351; Kansas City 
However, this does not necessarily mean that Gross was entirely ineffective. It is important to appreciate the distinction between "positive" and "negative" power in the legislaturethe ability, respectively, either to pass new legislation or to block new laws and preserve the existing status quo. As a champion of fiscal restraint, Gross had relatively little interest in passing additional measures; instead, he focused on blocking new spending proposals, and the record shows many examples of him working to oppose new raids on the federal treasury. When a 1964 bill attempted to raise the pay of congressmen and other federal employees, for example, Gross forced a roll call vote on the measure. The Des Moines Register believed that his tactic had led to the bill's defeat, since many members were unwilling to go on record in support of it. Happily for Gross, his general stance complemented the basic nature of the congressional policymaking process, which tends to give the advantage to the exercise of negative power. One of the most fundamental aspects of congressional lawmaking is its inherent bias toward the status quo. In the long legislative process, with its many individual steps, each new proposal typically has to win majority approval at every step, offering multiple opportunities to block, stall, or kill new legislation. ${ }^{58}$

One specific form of obstructionism, however-Gross's exercise of parliamentary procedures - was less effective than commonly supposed. Talented parliamentarians are often presumed to wield great clout in the House, yet their efforts rarely constitute more than a delaying tactic. The House lacks the Sen-

Star, 7/12/1958; Baker, House and Senate, 91-92. H.R. 144 was designed "to provide that federal expenditures shall not exceed Federal revenues except in time of war or grave national emergency declared by the Congress, and to provide for systematic reduction of the federal debt." See Congressional Record 105, part 16, index, 86th Cong., lst sess. (Washington, DC, 1960), 1058. A survey of the Congressional Record from 1949 through 1974 shows that Gross introduced an average of between 11 and 12 bills per legislative session. Few, if any of the bills constituted major legislation. A number of bills dealt with agricultural issues and Post Office matters. See Congressional Record 95, part 1, index through vol. 120, part 32, index (Washington, DC, 1949-1974).

58. Des Moines Register, 3/13/1964; Roger H. Davidson and Walter J. Oleszek, Congress and Its Members, 3rd ed. (Washington, DC, 1990), 308; Smith, American Congress, 50-51. 
ate's tradition of individualism, a practice that grants real power to individual members and allows a single senator to impede or even scuttle legislation. In the House, the rules permit the majority party and its leaders to "work their will." Accordingly, even a strong parliamentarian such as Gross typically could not hope to do more than slow down the spending train; tactics such as demanding quorum calls and opposing unanimous consent could be used to harry opponents and cause delays, but ultimately not to block most legislation. No matter how skilled, one rank-and-file House parliamentarian simply could not have a major legislative effect. ${ }^{59}$

Clearly, then, Gross's influence was affected by broad factors within Congress. By itself, however, such an explanation is incomplete. Party balances and institutional structures are basic features of the legislature, and parliamentary skills are wielded by a variety of members. Thus, general factors cannot explain Gross's unique role and notoriety. Understanding his impact requires specific attention to his unique personal and legislative style. Several factors are particularly important here: Gross's focus on financial matters and scandals, his practice of legislating from the House floor, his personality and style, and the lavish attention he received from the news media.

Although Gross wore the general mantle of "Watchdog of the Treasury," he focused primarily on a smaller subset of legislation, prioritizing financial matters such as pay raises, junketing, lavish spending, and other questionable congressional practices such as attempts to boost congressional perks through "backdoor" means. Such matters have at least one thing in common: members who engage in them risk the appearance of malfeasance or impropriety, which can be exploited by rivals, and can thus potentially affect the members' future chances for reelection. Obviously, members would prefer that such matters not receive much attention. Gross stood in the way of such obfuscation. His detailed scrutiny of floor bills meant that such activities were likely to be discovered and brought to light. And all of that activity was likely to occur in a highly public place, the House floor, which is much more visible than the various

59. Baker, House and Senate, 27. 
committee chambers. As Woodrow Wilson had observed, "Congress in session is Congress on public exhibition." 60

For all these reasons, H. R. Gross was tailor-made for the media. His self-chosen legislative mandates held intrinsic interest for the press. Questionable expenditures and other seeming improprieties have always tended to draw press attention. The media like to highlight conflict and controversy, and scandal and impropriety are perennial subjects of interest. Accordingly, Gross's actions tended to attract a significant press following. His personality probably further heightened the media attention. His wit and humor served as a draw, and his pithy quotes provided highly desired color for reporters writing stories on the doings of Congress. Gross was said to greet new legislation with quips such as "Just what's in this turkey?" or "How much will this boondoggle cost?" As one writer noted, H. R. Gross was the "best show in town." 61

Thus, Gross's ability to focus attention on controversial matters seemed to grant him some measure of legislative clout. Other House members often took Gross into account as they considered or devised legislation. If their bill fell into one of the categories that interested Gross, they knew that it would probably attract his attention, and that his reaction might then prove embarrassing. Indeed, the whole affair might even end up in the news. Accordingly, some evidence suggests that spending bills were trimmed, revised, or even killed in anticipation of Gross's response. An article on Gross noted, "Many committee chairmen try to iron out possible differences with Gross by notifying him of their intentions in advance. Some congressmen report that they have changed legislation in committee to anticipate Gross's objections on the floor." Another piece quoted an anonymous colleague as saying, "I've attended many committee hearings when the chairman will study a bill and make sure we can answer the knotty questions Gross will ask. Many times items will be dropped before the bill hits the floor because

60. Paul S. Herrnson, Congressional Elections: Campaigning at Home and in Washington, 2nd ed. (Washington, DC, 1998), 145, 193; Wilson, Congressional Government, 69.

61. Louviere, "The House is Losing," 24; Kauffman, "The Eternal Flamethrower"; Wanniski, "With Jeers and Jests." 
of him." This sort of situation - involving the hidden exercise of power - has attracted substantial interest from political scientists. Although the publicly apparent exercise of influence is the most visible face of power, the quiet, invisible suppression or modification of proposals can also be important. Unfortunately, however, this second, veiled face of power can be far more difficult to detect, measure, or study. Thus, while it is hard to gain a firm grasp of how much influence Gross wielded in this less visible manner, available evidence suggests that it was considerable. ${ }^{62}$

Despite the difficulties, it is tempting to try to devise a more precise measure of Gross's legislative clout. Given his focus on financial matters, one approach would be to focus on actual levels of spending, since dollars offer a precise standard for measurement. Even here, however, one's conclusions ultimately rest on how the matter is framed. In one sense, Gross could be seen as having had little effect; he could embarrass colleagues on questionable or difficult to defend expenditures, but that left him with little influence over other, broader spending categories. He often opposed outlays in a variety of general areas, but his one vote had little impact on the overall outcomes. Viewed in percentage terms, then, Gross's impact on reducing federal expenditures was slight; because he affected only a small percentage of budget items, he could affect only a small percentage of the budget. Considering actual dollar amounts, however, Gross fares better. One author noted, "It is conservatively estimated he has saved the taxpayer hundreds of millions of dollars. The total may even run into billions." 63

Whatever the value of the financial savings Gross achieved, it would be a mistake to assess his influence only in that light. He made several more general contributions to the House. For one, he helped to facilitate an improved style of deliberation on the floor. Because of his nearly constant presence and his willingness to engage in debate, he was involved in a substantial

62. Leslie, “Uncle Sucker,” 41; Bauman, “H. R. Gross,” 8; Peter Bachrach and Morton S. Baratz, "Two Faces of Power," American Political Science Review 56 (1962), 948-49.

63. Louviere, "The House is Losing," 23. It is important to note that sources can vary widely in their estimates of the "savings" Gross was responsible for. See Des Moines Register, 11/5/1961. Commenting in 1965, House Speaker Carl Albert cited the figure of "many millions of dollars." Bauman, "H. R. Gross," 8. 


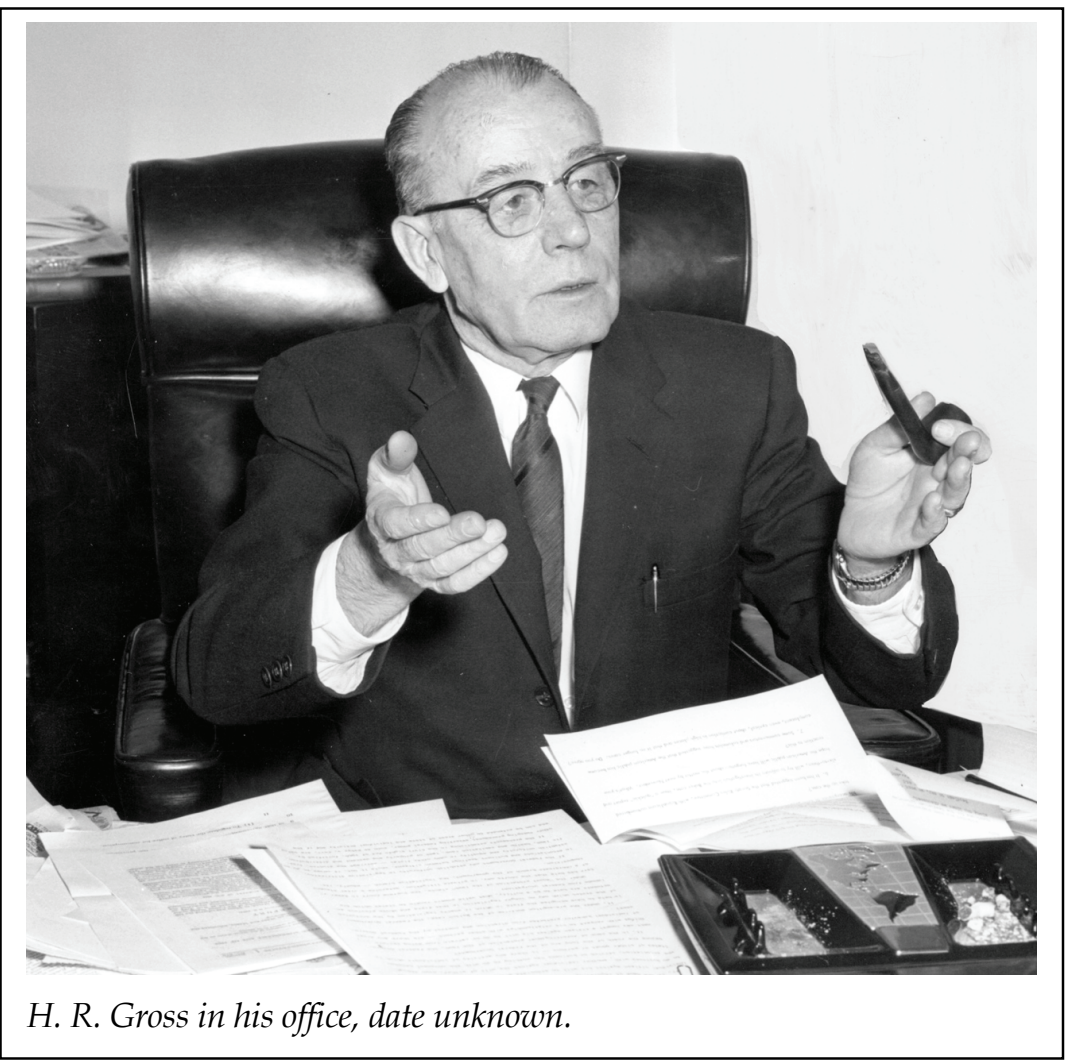

amount of deliberation, and his contribution to the quality of deliberation matched his contribution to the quantity of deliberation. One author noted that Gross "is generally well prepared, he is a good debater ... and his questions are germane." Longtime Georgia Representative Carl Vinson once remarked, "There is really no good debate unless the gentleman from Iowa is in it." Some House observers have raised serious questions about the general quality of congressional deliberation-suggesting that it is not a priority for many members. Gross, however, dedicated his congressional career to raising the standard of deliberation in the chamber. Furthermore, Gross's attentions seem to have ensured a closer fidelity to rules and other official standards of operation. Republican James Utt of California once stated that other members of the House "have come to rely on 
Representative Gross to do much of their work, and they have come to rely upon him to stop rule violations." Finally, and most generally, Gross's legislative style was a means to a broader end. With his careful scrutiny of bills, his fealty to prudent spending (at least as he saw it) and his uncompromising insistence on integrity, Gross brought a measure of accountability to the chamber. The U.S. House is a sprawling body, and, to a significant degree, it is a fragmented and decentralized one. Accordingly, it suffers from a lack of centralized focus or accountability. In his own way, Gross provided some such accountability; members who tried to pass weak or questionable legislation knew they would likely have to answer for it. John Bell Williams, a Democratic congressman from Mississippi, once declared that Gross was "the most valuable single member of the House" largely because of his close scrutiny of all legislation. On the occasion of Gross's retirement, Minority Leader Gerald Ford said that he was sorry to see Gross go, adding, "I have had the greatest admiration for H. R.'s dedication to the principle that every penny of federal spending must be scrutinized by the Congress." Ford concluded, "Future Congresses will miss H. R. Gross, but the taxpayer will miss him more." 64

DURING GROSS'S TIME IN CONGRESS, a picture hung on the wall of his office in Washington. The photo showed a municipal swimming pool in Rockwell, Iowa, a town in Gross's district, and the caption declared, "Constructed without ANY federal funds, 1967." 65 That, perhaps as much as anything, seems to capture H. R. Gross's spirit: a flinty insistence on fiscal prudence and a strong work ethic, manifested in a straightforward style and a willingness to sacrifice popularity in order to pursue the principles he held dear.

64. Leslie, "Uncle Sucker," 40; Mills, "Remarkable Mr. Gross," 11; Charles A. Vanik, "Congress is Deliberative: Compared to What?" in The United States Congress: Proceedings of the Thomas P. O'Neill, Jr. Symposium on the U.S. Congress (Chestnut Hill, MA, 1982), 13-19; Des Moines Register, 9/20/1962; Lawrence C. Dodd, "Congress and the Quest for Power," in Congress Reconsidered, ed. Lawrence C. Dodd and Bruce I. Oppenheimer (New York, 1977), 283-89; Loomis, The Contemporary Congress, chap. 2; Ames Daily Tribune, 1/18/1974.

65. Bauman, "H. R. Gross," 7. 
The essentials of Gross's style had been nurtured early, rooted in a boyhood on a southern Iowa farm, and honed by a close-up view of the effects of the Great Depression. Those experiences led to a lifelong belief in the virtue of agriculture, a lifelong dedication to the farmer, and, more broadly, a populist philosophy, originally seen by many as radical, that came to be viewed as staunch conservativism. Those principles would shape his tenure in Congress, where he fought for his causes for 26 years.

After he retired in 1974, Gross did not return to Iowa; instead, he and Hazel remained in Washington, where he died on September 22, 1987. He was buried in Arlington National Cemetery. Perhaps he and his wife had remained in Washington to be near friends or family, or perhaps, while he retained his simple personal lifestyle, Gross had grown comfortable in a town with which he had so often seemed to be so much at odds.

It was a town that, seemingly, had grown comfortable with H. R. Gross. He certainly had his detractors, but Gross did win widespread respect from his colleagues on both sides of the aisle. One account described an informal ceremony, marking Gross's birthday, that took place on the House floor: "One congressman after another arose to pay tribute to the little man from Iowa who had caused them so much 'trouble' over the years." For all of Gross's prickliness and dour disposition, others seemed to sense his deep personal integrity and to recognize the manifold and unique contributions he made to the House. Recognizing Gross's contradictions, as well as his strengths, perhaps this perspective summarizes things best: A Congress filled with men like Gross would be unworkable, but Congress nonetheless needs one man like H. R. Gross. ${ }^{66}$ 